\title{
Effect of Replacement of Conventional Feeds by Prosopis juliflora Pods and Citrullus lanatus Seed Cake on Nutrient Utilization in Marwari Goats
}

\author{
Dharmendra Chharang ${ }^{1 *}$, Tribhuwan Sharma ${ }^{1}$, Vijay Pandey ${ }^{2}$, Hemant Joshi ${ }^{3}$ and \\ Surendra Singh Shekhawat ${ }^{3}$ \\ ${ }^{1}$ College of Veterinary and Animal Sciences, Rajasthan University of Veterinary and Animal Sciences, Bikaner, INDIA \\ ${ }^{2}$ College of Veterinary Science and Animal Husbandry, DUVASU, Mathura, INDIA \\ ${ }^{3}$ Post Graduate Institute of Veterinary Education \& Research, Rajasthan University of Veterinary and Animal Sciences, \\ Jaipur, INDIA \\ "Corresponding author: D Chharang; E-mail: dchharang@gmail.com
}

Received: 02 July, 2020

Revised: 23 July, 2020

Accepted: 26 July, 2020

\begin{abstract}
A study was organized to evaluate the effect of replacement of barley and cottonseed cake by mesquite Prosopis juliflora pods (PJP) and watermelon seed (WMS) cake, respectively in complete feed with sixteen Marwari buckling goats. They were divided into four groups of four animals in each. Four complete feed designated as $\mathrm{T}_{1}, \mathrm{~T}_{2}, \mathrm{~T}_{3}$ and $\mathrm{T}_{4}$ were prepared. $\mathrm{T}_{1}$ served as control having all the conventional ingredients whereas barley of control was replaced by mesquite PJP in $\mathrm{T}_{2}$, cottonseed cake was replaced by WMS (Citrullus lanatus) cake in $\mathrm{T}_{3}$ and both barley and cottonseed cake were replaced by mesquite PJP and WMS cake in $\mathrm{T}_{4}$, respectively. The DM intakes, digestibility of DM and gross nutrients, digestible nutrient intake, feed efficiency, were worked out for all the groups. Significant effects of treatment on DM intake, digestibility of CP were observed whereas effects on digestibility of DM, EE, CF and NFE were non-significant. It is concluded that both barley and cottonseed cake could be safely and effectively replaced by the mesquite PJP and WMS cake alone or in combination in the complete feed of goats.
\end{abstract}

\section{HIGHLIGHTS}

(0 Evaluation of effect of replacement of conventional feeds by nonconventional feeds.

(0 To study the effect on nutrient utilization in goats.

(0 Effectively replaced the barley and cottonseed cake by mesquite PJP and WMS cake.

Keywords: Digestibility, mesquite Prosopis juliflora pods, watermelon seed cake

Chronic feed shortage exhibit a major constraint to animal production in developing and underdeveloped countries due to the increasing human and livestock population and their activities continue to impose tremendous pressure on available feed resources. It has deflected most of the research in the field of animal nutrition to look into all prospects to conquer this nutritional crisis. The most viable proposition could be the inclusion of new nonconventional feed resources viz. tapioca waste, PJP, WMS cake and karanj cake, etc. in ration with suitable complete feed technology (Chharang et al., 2019).

Prosopis juliflora is a very variable, evergreen tree or shrub distributed in the arid part of tropical and subtropical regions. The ripen highly palatable pods produced as fruit, are moderate in crude protein $(12.58 \%)$ and rich in free sugar (19.51\%) giving sweet taste to it; making potentially usable for the feeding of livestock (Hintsa et al., 2015). Similarly, watermelon (Citrullus lanatus) is also a naturally grown xerophyte found in abundance in hot arid and semiarid areas. The seeds obtained from this plant are gaining

How to cite this article: Chharang, D., Sharma, T., Pandey, V., Joshi, H. and Shekhawat, S.S. (2020). Effect of replacement of conventional feeds by Prosopis juliflora pods and Citrullus lanatus seed cake on nutrient utilization in Marwari goats. J. Anim. Res., 10(4): 551-555.

Source of Support: None; Conflict of Interest: None 


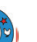

Chharang et al.

Table 1: Chemical composition of complete feeds and different feed ingredients (per cent DM basis)

\begin{tabular}{|c|c|c|c|c|c|c|c|c|c|}
\hline Feed ingredients & DM & $\mathbf{O M}$ & $\mathbf{C P}$ & $\mathbf{E E}$ & $\mathbf{C F}$ & NFE & Ash & $\mathrm{Ca}$ & $\mathbf{P}$ \\
\hline \multicolumn{10}{|l|}{ Complete feeds } \\
\hline $\mathrm{T}_{1}$ & 91.84 & 90.88 & 13.94 & 2.81 & 22.19 & 52.00 & 9.06 & 1.15 & 0.44 \\
\hline $\mathrm{T}_{2}$ & 92.48 & 90.28 & 14.05 & 3.16 & 25.85 & 47.28 & 9.66 & 1.22 & 0.41 \\
\hline $\mathrm{T}_{3}$ & 91.64 & 90.96 & 13.62 & 3.15 & 24.75 & 49.50 & 8.98 & 1.15 & 0.37 \\
\hline $\mathrm{T}_{4}$ & 92.28 & 90.36 & 13.73 & 3.50 & 28.41 & 44.78 & 9.58 & 1.22 & 0.34 \\
\hline \multicolumn{10}{|l|}{ Feed ingredients } \\
\hline Sewan & 91.81 & 92.49 & 4.62 & 1.78 & 32.82 & 53.07 & 7.51 & 1.27 & 0.05 \\
\hline Barley & 88.70 & 95.79 & 11.62 & 1.75 & 4.51 & 77.91 & 4.21 & 0.16 & 0.33 \\
\hline Mesquite PJP & 91.88 & 92.78 & 12.16 & 3.48 & 22.78 & 54.36 & 7.22 & 0.51 & 0.19 \\
\hline Cottonseed cake & 92.18 & 90.37 & 25.74 & 6.56 & 23.39 & 34.68 & 9.63 & 0.31 & 1.18 \\
\hline WMS cake & 91.07 & 90.84 & 23.95 & 8.46 & 37.60 & 20.83 & 9.16 & 0.34 & 0.78 \\
\hline Guar korma & 96.66 & 91.98 & 45.83 & 3.92 & 7.67 & 35.51 & 8.02 & 1.27 & 0.16 \\
\hline Min. mixture & 96.78 & - & - & - & - & - & 96.78 & 29.60 & 12.35 \\
\hline Common salt & 96.23 & - & - & - & - & - & 96.23 & - & - \\
\hline
\end{tabular}

DM-Dry matter, OM-Organic matter, CP-Crude protein, EE-Ether extract, CF-Crude fiber, NFE- Nitrogen free extract, PJP-Prosopis juliflora pod, WMS-watermelon seed.

commercial importance due to its high oil contents and cake is obtained as a by-product (Chharang et al., 2005). After extraction of oil from seeds, huge edible biomass is available for the feeding of animals having about $25.4 \%$ CP, 27.4\% CF and 7.84\% EE (Mustafa and Alamin, 2012).

The aim of the current study was to evaluate the effects of incorporation of mesquite PJP and WMS cake in complete feed on nutrient utilization of goats.

\section{MATERIALS AND METHODS}

\section{Experimental design, animals and diets}

Sixteen Marwari buckling goats of 7-8 months age were taken and divided into four groups of four animals in each using a completely randomized block design. Four iso-nitrogenous and nearly iso-caloric complete rations were formulated on DM basis and designated as $\mathrm{T}_{1}, \mathrm{~T}_{2}$, $\mathrm{T}_{3}$ and $\mathrm{T}_{4}$ as shown in Table 1 . In $\mathrm{T}_{1}$ (control) barley and cottonseed cake were incorporated in the complete feed as conventional energy and protein sources. Whereas in $\mathrm{T}_{2}$ the barley of control was replaced by non-conventional mesquite PJP, in $\mathrm{T}_{3}$ cottonseed cake of control was replaced by non-conventional WMS cake and in $\mathrm{T}_{4}$ both barley and cottonseed cake were replaced by mesquite PJP and WMS cake (Table 2).
Table 2: Parts composition of complete rations

\begin{tabular}{llllll}
\hline Sl. No. & Ingredients & $\mathbf{T}_{\mathbf{1}}$ & $\mathbf{T}_{\mathbf{2}}$ & $\mathbf{T}_{\mathbf{3}}$ & $\mathbf{T}_{\mathbf{4}}$ \\
\hline 1 & Sewan grass & 50 & 50 & 50 & 50 \\
2 & Barley & 20 & - & 20 & - \\
3 & Mesquite PJP & - & 20 & - & 20 \\
4 & Cottonseed cake & 18 & 18 & - & - \\
5 & WMS cake & - & - & 18 & 18 \\
6 & Guar korma & 10 & 10 & 10 & 10 \\
7 & Mineral Mix & 01 & 01 & 01 & 01 \\
8 & Salt & 01 & 01 & 01 & 01 \\
\hline
\end{tabular}

PJP-Prosopis juliflora pod, WMS-watermelon seed.

\section{Digestibility trials}

All the animals were subjected to feeding trial of 105 days, followed by seven days digestibility trial for estimation of digestibility of the different nutrients. The faeces, collected in $24 \mathrm{hrs}$, were weighed and mixed uniformly. A representative sample of about $10 \%$ of the total faeces excreted by each animal was taken for determination of $\mathrm{DM}$ in a hot air oven and these oven-dried samples were weighed and ground to about $1 \mathrm{~mm}$ size. The DM intakes, digestibility of DM and gross nutrients, digestible nutrient intake, feed efficiency, were worked out for all the groups 
for the entire experimental period. The feed and faecal samples were analyzed for proximate constituents by procedures of AOAC (1990).

\section{Statistical methods}

The statistical analysis for different parameters was analyzed using the conventional statistical procedure. The significance of mean differences was tested by Duncan's New Multiple Range Test (Steel et al., 1997).

\section{Ethical considerations}

All applicable national, international and institutional guidelines for the care and handling of animals were followed during experiment.

\section{RESULTS AND DISCUSSION}

The acceptability of feed is apparently one of the prime parameters for ascertaining utilizability of the new nonconventional feed resource. The overall DM intakes in all treatment groups are shown in Table 3. The statistical analysis revealed significantly lower palatability in $T_{2}, T_{3}$ and $\mathrm{T}_{4}$ in comparison to control, i.e. $\mathrm{T}_{1}$. However, mean palatability in $T_{2}, T_{3}$ and $T_{4}$ did not exhibit significant differences from each other.

Table 3: Overall mean and standard error values of DM Intake ( $\mathrm{kg} / 100 \mathrm{~kg}$ body wt.) and feed efficiency at fortnight intervals (Period 105 days) in all treatment groups

\begin{tabular}{lllll}
\hline Parameters & $\mathbf{T}_{1}$ & $\mathbf{T}_{2}$ & $\mathbf{T}_{3}$ & $\mathbf{T}_{4}$ \\
\multirow{2}{*}{ DM Intake } & $3.81^{\mathrm{b}} \pm$ & $3.70^{\mathrm{a}} \pm$ & $3.68^{\mathrm{a}} \pm$ & $3.64^{\mathrm{a}} \pm$ \\
& 0.05 & 0.03 & 0.04 & 0.03 \\
\hline \multirow{2}{*}{ Feed Efficiency } & $0.108^{\mathrm{b}} \pm$ & $0.096^{\mathrm{ab}} \pm$ & $0.096^{\mathrm{ab}} \pm$ & $0.077^{\mathrm{a}} \pm$ \\
& 0.006 & 0.006 & 0.007 & 0.006 \\
\hline
\end{tabular}

$\mathrm{P}<0.05, \mathrm{P}<0.01$.

The digestibility of DM and gross nutrients as shown in Table 4 could not reveal any significant differences due to effect of treatment except the crude protein which exhibited significantly higher digestibility in $T_{1}$ and $T_{2}$ in comparison to $\mathrm{T}_{3}$ and $\mathrm{T}_{4}$. Practical nutritional worth, i.e. DCP, TDN and NR and intake of digestible nutrients are shown in Table 4.

Regarding feed efficiency, as shown in Table 3, significant differences were observed among the treatment groups with maximum efficiency in $T_{1}$ and minimum in $T_{4}$.

Table 4: Digestibility coefficient of nutrients, digestible nutrient component and intake of digestible nutrients in all treatment groups

\begin{tabular}{lllll}
\hline Parameter & $\mathbf{T}_{\mathbf{1}}$ & $\mathbf{T}_{\mathbf{2}}$ & $\mathbf{T}_{\mathbf{3}}$ & $\mathbf{T}_{4}$ \\
\hline Digestibility coefficient (\%) & & & \\
\hline $\mathrm{DM}$ & $64.82 \pm$ & $62.42 \pm$ & $65.18 \pm$ & $61.40 \pm$ \\
& 2.18 & 2.90 & 0.85 & 1.69 \\
$\mathrm{CP}$ & $72.49^{\mathrm{b}} \pm$ & $72.89^{\mathrm{b}} \pm$ & $67.79^{\mathrm{a}} \pm$ & $67.52^{\mathrm{a}} \pm$ \\
& 1.00 & 0.97 & 1.54 & 1.65 \\
$\mathrm{EE}$ & $78.05 \pm$ & $79.88 \pm$ & $82.48 \pm$ & $84.19 \pm$ \\
& 3.45 & 1.10 & 1.50 & 1.63 \\
$\mathrm{CF}$ & $57.49 \pm$ & $53.69 \pm$ & $60.27 \pm$ & $55.83 \pm$ \\
& 3.19 & 5.44 & 1.49 & 4.06 \\
$\mathrm{NFE}$ & $67.18 \pm$ & $66.40 \pm$ & $68.12 \pm$ & $65.91 \pm$ \\
& 1.86 & 1.66 & 1.63 & 1.01 \\
\hline Digestible nutrient component (\%) & & \\
\hline DCP & 10.10 & 10.24 & 9.23 & 9.27 \\
TDN & 62.72 & 55.51 & 63.72 & 61.28 \\
NR & $1: 5.21$ & $1: 4.42$ & $1: 5.90$ & $1: 5.61$ \\
\hline Intake of digestible nutrients (g/day) & & \\
\hline DCP & 68.58 & 69.53 & 61.84 & 62.66 \\
TDN & 425.87 & 376.91 & 426.92 & 414.25 \\
\hline
\end{tabular}

$\mathrm{P}<0.01$.

DCP- Digestible Crude Protein, TDN- Total Digestible Nutrients, NR- Nutritive ratio.

The nutrient contents of the mesquite PJP and WMS cake used in the current study were observed similar to previous studies (Batista et al., 2002; Obeidat et al., 2013) and (Mustafa and Alamin, 2012), respectively. However, CP contents in processed WM seeds were observed by Rekha and Rose (2016) and Milala et al. (2018) as 68.4\% and $68.04 \%$, respectively.

A significant drop in palatability and a non-significant drop in DM intake in $\mathrm{T}_{3}$ are in agreement with the earlier finding of Swami (1995). No adverse effect due to the inclusion of mesquite PJP in $\mathrm{T}_{2}$ and $\mathrm{T}_{4}$ on DM intake could be attributed to the fact that both barley and mesquite PJP are equally acceptable to the buckling goats.

The high acceptability of mesquite PJP have also been reported earlier by Sharma (1997) in sheep and Talpada 
et al. (2002) in cattle, Obeidat et al. (2013) in sheep and observed no adverse effect on DM intake due to inclusion of mesquite PJP in the ration. However, results were inconsistent in sheep and goat with Abdullah and Hafes (2004) and Mahgoub et al. (2005), respectively.

The results of digestibility of DM in present investigation fall in line with finding of Talpada et al. (2002) and Obeidat et al. (2013) as they observed no adverse effect or even a little increase in the digestibility of DM in ruminants on feeding mesquite PJP in the complete feeds replacing conventional ingredients. Sharma et al. (1997) also observed no significant effect of replacement of conventional energy sources by mesquite PJP in ruminants. However, the result was inconsistent with Abdullah and Hafes (2004). The non-significant effect of replacement by WMS cake on DM digestibility has also been in agreement with earlier findings of Swami (1995) and Sharma (2001). However, Mustafa and Alamin (2012) observed lower DM degradability in WMS cake than whole WM Seeds and pulp, respectively.

The statistical analysis of the digestibility of crude protein revealed highly significant $(P<0.01)$ effect of treatment. The comparison of means indicated significantly lower per cent digestibility of crude protein in animals of $T_{3}$ and $\mathrm{T}_{4}$ groups in comparison to that observed in animals of $T_{1}$ and $T_{2}$ groups. However, the significant differences could not be noticed between $T_{1}$ and $T_{2}$ where barley was replaced by mesquite PJP as well as between $\mathrm{T}_{3}$ and $\mathrm{T}_{4}$ where cottonseed cake was replaced by WMS cake alone $\left(\mathrm{T}_{3}\right)$ and in combination with mesquite PJP replaced barley $\left(\mathrm{T}_{4}\right)$. These results suggest that replacement of barley by mesquite PJP did not adversely affect the digestibility of crude protein and the finding is also in agreement with Talpada et al. (2002). But, the inclusion of WMS cake in $\mathrm{T}_{3}$ and $\mathrm{T}_{4}$ alone or combination exhibited a decrease in digestibility of crude protein. A decrease in digestibility of crude protein has also been reported by other workers viz., Singh et al. (1992) and Swami (1995). However, Mustafa and Alamin (2012) observed higher CP degradability in WMS cake following the pulp and whole seed.

The statistical analysis of data did not show any significant effect of treatment on ether extract and crude fibre digestibility. The results obtained are in line with the earlier findings of Swami (1995), Sharma et al. (1997) and Talpada et al. (2002). However, the values obtained in all the four treatment groups fed complete feeds in the present investigation are higher for ether extract and lower for crude fibre than the values obtained by Sharma (2001) on feeding complete feed to goats.

The statistical analysis of NFE revealed a non-significant effect of treatment. Results found by Sharma (1997) and Talpada et al. (2002) on feeding the non conventional mesquite PJP supports the result. No adverse effect was observed on NFE digestibility on the inclusion of WMS cake in $T_{3}$ and $T_{4}$. The NFE digestibility values are in accordance with the earlier results of Talpada et al. (2002) in calves and Sharma (2001) in kids on feeding complete feeds. Contrary to it, Swami (1995) observed an increase in NFE digestibility.

The DCP and TDN values of $T_{2}$ feed are in accordance to the findings of Talpada et al. (2002) as they found DCP and TDN values of complete feed having mesquite PJP to be $12.00 \%$ DCP and $55.90 \%$ TDN. The DCP and TDN recorded for $\mathrm{T}_{3}$ feed, however, do not correspond with values obtained by Sharma (2001) in goats.

The non-significant effect on feed conversion efficiency attests the earlier results on the inclusion of mesquite PJP by Sharma (1997) and Talpada et al. (2002) and WMS cake by swami (1995) and Sharma (2001). The feed efficiency in $\mathrm{T}_{4}$ was noticed to be significantly lower than $\mathrm{T}_{1}$, i.e. control. Whereas, mean feed efficiency in $\mathrm{T}_{2}$ and $\mathrm{T}_{3}$ groups were neither significantly different from $\mathrm{T}_{1}$ nor $\mathrm{T}_{4}$ and were almost same in both the treatment groups. The findings indicate that replacement of conventional feed by non-conventional feed has not adversely affected the efficiency of complete feeds.

\section{CONCLUSION}

It is concluded that both barley and cottonseed cake could be effectively replaced by the mesquite Prosopis juliflora pods (PJP) and watermelon seed (WMS) cake alone as well as in combination in complete feed.

\section{REFERENCES}

Abdullah, A. and Hafes, B.A. 2004. Inclusion of Prosopis juliflora pods in finishing Awassi lamb diets. In: Proc. 11 AAAP Anim. Sci. Cong., 2: 373-375.

AOAC. 1990. Official methods of analysis. $15^{\text {th }}$ ed. Association of Official Analytical Chemists, Washington, D.C. 
Batista, A.M., Mustafa, A.F., McKinnon, J.J. and Kermasha, S. 2002. In situ ruminal and intestinal nutrient digestibility of mesquite (Prosopis juliflora) pods. Anim. Feed Sci. Technol., 100: 107-112.

Chharang, D., Saini, V.P., Chopra, D. and Choudhary, S. 2019. Current and future perspective of biotechnological applications in livestock nutrition: a review. Int. J. Curr. Microbiol. Appl. Sci., 8: 973-982.

Chharang, D., Sharma, T., Arya, R.S., Dhuria, R.K., Singh, A.P. and Garg, D.D. 2005. Effect of incorporation of mesquite (Prosopis juliflora) pods and matira seed (Citrullus lanatus) cake in complete feed for goats on certain rumen metabolites. In: Proc. $5^{\text {th }}$ Indian Veterinary Congress and XII annual conference of IAAVR, 237-245.

Hintsa, K., Balehegn, M. and Birhane, E. 2015. Utilization of pods of Prosopis juliflora, an invasive tree, as a replacement to concentrate feed for goats in Ethiopia. Livest Res Rural Dev., 27: 9.

Mahgoub, O., Kadim, I.T., Forsberg, N.E., Al-Ajmi, D.S., Al-Saqri, N.M., Al-Abri, A.S. and Annamalai, K. 2005. Evaluation of Meskit (Prosopis juliflora) pods as a feed for goats. Anim. Feed Sci. Technol., 121: 319-327.

Milala, M.A., Luther, A. and Burah, B. 2018. Nutritional comparison of processed and unprocessed Citrillus lanatus (watermelon) seeds for possible use in feed formulation. Am. J. Food Nutri., 6: 33-36.

Mustafa, A.B. and Alamin, A.A.M. 2012. Chemical composition and protein degradability of watermelon (Citrullus lanatus) seeds cake grown in Western Sudan. Asian J. Anim. Sci., 6: 33-37.
Obeidat, B.S. and Shdaifat, M.M. 2013. Partial substitution of barley grain with Prosopis juliflora pods in lactating Awassi ewes' diets: Effect on intake, digestibility and nursing performance. Small Rumin. Res., 111: 50-55.

Rekha, G. and Rose, A.L. 2016. Proximate nutritional analysis of dried watermelon seed. Int. J. Eng. Res. Gen. Sci., 4: 4446.

Sharma, S. 2001. Efficiency of utilization of non conventional protein sources in complete feed of Marwari goats for growth and lactational performance, $\mathrm{PhD}$ Thesis, Rajasthan Agriculture University, Bikaner, India.

Sharma, T. 1997. Efficiency of utilization of processed mesquite pods in the ration of sheep, $\mathrm{PhD}$ Thesis Rajasthan Agricultural University, Bikaner, India.

Singh, P., Agarwala, O.N. and Jain, V.V. 1992. Effect of feeding deoiled mahua (Bassia latifolia) seed cake with or without aqueous alcohol treatment on growth and nutrient utilization in lambs. Indian J. Anim. Nutr., 9: 168-171.

Steel, R.G.D., Torrie, J.H. and Dickey, D.A. 1997. Principles and Procedures of Statistics. A Biometrical Approach- $3^{\text {rd }}$ ed. McGraw Hill Book Company, New York, USA.

Swami, R. 1995. Effect of replacement of cotton seed cake by graded levels of matira cake (Citrulus lanatus) in the ration of dairy calves. MVSc Thesis Rajasthan Agricultural University, Bikaner, India.

Talpada, P.M., Pandya, P.R., Patel, G.R., Patel, D.C. and Desai, M. 2002. Utilization of complete feed using Prosopis juliflora pods a ration of growing crossbred calves. Indian J. Anim. Nutr., 19: 1-6. 
